\title{
Keefektifan Model Pembelajaran Mind Mapping pada Penulisan Cerita Pendek Ditinjau dari Kecerdasan Emosional Siswa Kelas 5 SDN Se Gugus Suryo Kecamatan Sine Kabupaten Ngawi Tahun Pelajaran 2021/2022
}

\author{
Lucia Siswantini $\bowtie$, Universitas PGRI Madiun \\ V. Teguh Suharto, Universitas PGRI Madiun \\ Dwi Rohman Soleh, Universitas PGRI Madiun
}

luciasiswantini2019@gmail.com

\begin{abstract}
Abstrak: Kemampuan siswa dalam menulis cerita pendek masih rendah, karena guru belum menerapkan pembelajaran inovativ sesuai kecerdasan emosional siswa. Rumusan penelitian ini yaitu 1) apakah ada perbedaan kemampuan menulis cerita pendek siswa dengan model pembelajaran peta konsep dengan model pembelajaran langsung? 2) Apakah ada perbedaan kemampuan menulis cerita pendek siswa yang kecerdasan emosionalnya tinggi dengan siswa yang kecerdasan emosionalnya rendah? 3) Apakah ada interaksi model pembelajaran dan kecerdasan emosional dalam mempengaruhi kemampuan menulis cerita pendek? Penelitian ini menggunakan metode quasi eksperiment dengan rancangan faktorial $2 \times 2$. Populasi penelitian yaitu siswa SD di Gugus 1 Kecamatan Sine Kabupaten Ngawi. Penelitian dilakukan mulai bulan Juli-Desember 2021. Sampel penelitian diambil sebanyak 4 SD dengan teknik sampling ialah multyple stage purposive sampling. Data penelitian diperoleh dengan menggunakan angket dan tes. Analisis data menggunakan teknik analisis varians klasifikasi ganda. Pengujian hipotesis diperoleh Fh model pembelajaran sebesar 42,08 dengan signifikansi 0,00. Fh kecerdasan emosi sebesar 118,73 dengan signifikansi 0,00. Fh interaksi model pembelajaran dan kecerdasan emosi sebesar 8,27 dengan signifikansi 0,00. Penelitian menyimpulkan bahwa: 1) ada perbedaan yang signifikan hasil belajar antara model Pembelajaran Peta Konsep dan Pembelajaran Langsung. 2) ada perbedaan Hasil Belajar Siswa yang Kecerdasan Emosinya tinggi dan rendah. 3) ada interaksi antara penggunaan model pembelajaran dan kecerdasan emosi dalam mempengaruhi hasil belajar.
\end{abstract}

Kata kunci: pembelajaran menulis cerita pendek, pembelajaran peta konsep, kecerdasan emosional

Abstract: Students' ability in writing short stories is still low, because teachers have not implemented innovative learning according to students' emotional intelligence. The formulation of this research is 1 ) is there a difference in students' ability to write short stories with the concept map learning model and the direct learning model? 2) Is there a difference in the ability to write short stories of students with high emotional intelligence and students with low emotional intelligence? 3) Is there an interaction between learning models and emotional intelligence in influencing the ability to write short stories? This study uses a quasi-experimental method with a $2 \times 2$ factorial design. The research population is elementary school students in Cluster 1, Sine District, Ngawi Regency. The study was conducted from July to December 2021. The research sample was taken as many as 4 elementary schools with a sampling technique that was multiple stage purposive sampling. Research data obtained by using a questionnaire and tests. Data analysis used multiple classification analysis of variance technique. Hypothesis testing obtained Fh learning model of 42.08 with a significance of 0.00 . Fh emotional intelligence is 118.73 with a significance of 0.00 . Fh interaction learning model and emotional intelligence of 8.27 with a significance of 0.00 . The research concludes that: 1 ) there is a significant difference in learning outcomes between the Concept Map Learning and Direct Learning models. 2) there are differences in the learning outcomes of students with high and low emotional intelligence. 3) there is an interaction between the use of learning models and emotional intelligence in influencing learning outcomes.

Keywords: learning to write short stories, learning concept maps, direct learning.

Citation: Siswantini, L., Suharto, V.T., \& Soleh, D.R. (2022). Keefektifan Model Pembelajaran Mind Mapping pada Penulisan Cerita Pendek Ditinjau dari Kecerdasan Emosional Siswa Kelas 5 SDN Se Gugus Suryo Kecamatan Sine Kabupaten Ngawi Tahun Pelajaran 2021/2022. Wewarah: Jurnal Pendidikan Multidisipliner, l(1), $148-155$.

(cc) $\mathrm{Br}$

Published by Program Pascasarjana Universitas PGRI Madiun. This work is licensed under the Creative Commons AttributionNonCommercial-ShareAlike 4.0 International License. 


\section{PENDAHULUAN}

Menulis merupakan salah satu kemampuan berbahasa yang bersifat produktif, karena menghasilkan suatu produk, yaitu tulisan. Seseorang perlu belajar merangkai kata atau kelompok kata, memilih kata yang sesuai dengan konteks kemudian merangkaikannya dalam kalimat dan paragraf dengan bahasa yang mudah dipahami oleh pembaca. Amstrong dalam Aksan (2011:15) memaparkan bahwa menulis dapat meningkatkan kecerdasan linguistic seseorang. Seseorang yang memiliki intelegensi linguistic akan mampu menggunakan dan mengolah kata-kata secara efektif baik secara lisan maupun tertulis.

Menjadi terampil menulis cerita pendek, seseorang perlu berlatih secara mandiri dan berlatih kecerdasan emosional secara intensif. Kesabaran dan kegigihan menjadi faktor utama seseorang belajar menulis cerita pendek secara mandiri. Penggunaan media dan model pembelajaran menulis cerita pendek yang baik belum banyak dilakukan di tingkat sekolah dasar. Berdasarkan penelitian PTK oleh tim guru, ditemukan fakta bahwa kemampuan siswa dalam menulis cerita pendek masih rendah.

Berdasarkan hasil wawancara yang dilakukan oleh peneliti dengan guru kelas V SDN Jagir 1 diperoleh informasi bahwa dalam pembelajaran menulis cerita pendek guru belum memaksimalkan dalam menerapkan pembelajaran inovator yang sesuai kecerdasan emosional siswa. Kondisi ini ditengarahi mengakibatkan siswa mengalami kesulitan dalam mengembangkan ide dan gagasan, dan pada akhirnya siswa hanya mencontoh cerita pendek yang sudah ada. Padahal untuk pembinaan penulis pemula cerita pendek, peranan guru sangat diperlukan untuk membimbing siswa mulai dari tahap memunculkan ide dan gagasan, mengembangkan ide dan gagasan sampai kepada tahap menulis cerita pendek secara utuh. Guru perlu menghadirkan model mengajar yang dapat memancing gagasan dan pengembangan keterampilan menulis siswa.

Banyak guru belum pernah menerapkan model pembelajaran yang dapat mengasah kecerdasan emosional siswa yang mendorong minat untuk menulis cerita pendek. Kebanyakan guru belum memperhatikan aspek kecerdasan emosional siswa ini dengan baik untuk mendorong keancaran pembelajaran menulis cerita pendek, padahal kecerdasan emosional itu sangat besar peranannya dalam proses dan hasil belajar. Hal ini sesuai dengan pendapat Haryadi dan Zamzami (1996:79) yang menyatakan bahwa pada tahap pramenulis, seorang penulis memerlukan ketajaman kecerdasan emosional dalam melakukan kegiatan beberapa hal, yaitu menemukan ide dan gagasan, menentukan judul karangan, menentukan tujuan, memilih bentuk atau jenis tulisan, membuat kerangka, dan mengumpulkan bahan-bahan kemudian dikembangkan menjadi sebuah tulisan yang baik.

Rendahnya kemampuan siswa dalam menulis cerita pendek karena siswa merasa kesulitan dalam memunculkan ide dan gagasan. Padahal, pemunculan ide dan gagasan merupakan salah satu proses kecerdasan emosional yang harus dilakukan sebelum menulis cerita pendek. Hal ini sesuai dengan pendapat Haryadi dan Zamzami (1996:79), yang menyatakan bahwa tahap pramenulis, seorang penulis melakukan kegiatan beberapa hal, yaitu menemukan ide dan gagasan, menentukan judul karangan, menentukan tujuan, memilih bentuk atau jenis tulisan, membuat kerangka, dan mengumpulkan bahanbahan kemudian dikembangkan menjadi sebuah tulisan yang baik.

Adanya pandemi covid-19, maka diambil kebijakan untuk menghindari penularan virus covid 19, yaitu sekolah diliburkan dan akhirnya pembelajaran harus dilakukan secara daring atau online. Kondisi ini semakin memperburuk keadaan karena sejak dari awal pembelajaran sudah tidak maksimal, kemampuan siswa masih rendah, sekarang tambah sulit lagi karena masa pandemi ini. Proses interaksi pendidikan yang dulu memberikan siswa secara kooperatif saling asah asih asuh, hal itu sekarang tidak dapat dilakukan. Semua siswa harus belajar secara mandiri sesuai dengan kecerdasan mereka masingmasing di rumah.

Berdasar latar belakang masalah, disusun rumusan masalah yang sekaligus tujuan penelitian yaitu: (1) Menemukan perbedaan kemampuan menulis cerita pendek antara siswa yang diajar dengan model pembelajaran peta konsep dengan siswa yang diajar dengan pembelajaran langsung; (2) Menemukan perbedaan kemampuan menulis cerita pendek antara siswa yang kecerdasan emosionalnya tinggi dengan siswa yang kecerdasan emosionalnya rendah; (3) Menemukan interaksi antara penggunaan model pembelajaran dan kecerdasan emosional dalam mempengaruhi kemampuan menulis cerita pendek.

Dari Kajian teoretik, disusun kerangka berpikir sebagai berikit. Model pembelajaran peta konsep menyatukan materi pembelajaran dengan alam kehidupan nyata, sehingga mendorong siswa membuat 
hubungan antara pengetahuan yang dimilikinya dengan praksis kehidupan sehari-hari. Pelajaran sangat menyenangkan dan memberikan makna karena siswa diberi kebebasan membangun konsep dan mencobakan konsep sendiri. Siswa membangun sendiri pengetahuan mereka melalui keterlibatannya secara aktif dan konstruktif dalam proses belajar sehingga memperoleh pengetahuan.

Pembelajaran dengan model peta konsep memiliki sifat siswa dihadapkan kepada lingkungan belajar yang bebas, kebebasan siswa merupakan unsur yang sangat esensial, kebebasan dipandang sebagai penentu keberhasilan, kontrol belajar dipegang oleh siswa, mengikuti pandangan siswa, aktivitas belajar dalam konteks nyata, menekankan pada proses. Sifat-sifat tersebut merupakan prasyarat berkembangnya kreativitas karena dengan situasi aman dan kebebasanlah kreativitas dapat terbentuk. Situasi bebas dan menyenangkan juga merangsang siswa untuk menggalakkan minat yang menjadikan mereka senang terlibat secara mendalam terhadap ranah tertentu.

Berbeda jauh dengan model peta konsep, model pembelajaran langsung mengandalkan adanya input yang merangsang respon anak. Pembelajaran berorientasi pada target penguasaan materi. Dalam pandangan behaviorstik, belajar merupakan aktivitas pengumpulan informasi, pengetahuan yang sudah jadi, statis, dan mekanis. Siswa dipandang sebagai kaleng kosong tempat ditumpahkannya semua pengetahuan dari guru. Guru menyebarkan informasi keilmuan dan siswa menerima, karena itu model pembelajaran langsung mengandalkan tranfer pengetahuan dengan penjejalan materi ke kepala anak. Cara transfer pengetahuan ini sering membelanggu siswa karena rata-rata siswa belum memiliki motivasi yang baik untuk belajar. Transfer pengetahuan sering dilakukan dengan teknik ceramah. Penggunaan teknik ceramah inipun membosankan, sehingga cenderung siswa tidak menyimak.

Memperhatikan perbedaan karakteristik dua model pembelajaran di atas, mana model pembelajaran peta konsep lebih mudah diikuti dan membawa dampak lebih baik dalam belajar. Berdasarkan kerangka berpikir ini, maka diduga kuat ada perbedaan dampak yang cukup signifikan antara ketiga model tersebut dalam menghasilkan kemampuan apresiasi prosa fiksi (Suharto, 2011: 35)

Prosa fiksi tidak merupakan hasil karya khayalan karena pengalaman jiwa tidak lepas dari dunia empiris pengarang. Pengalaman dunia empiris itu dimasukkan dalam pengalaman batin, mengendap dalam dirinya untuk kemudian diekspresikan melalui daya kreatifnya. Pengarang melalui karyanya ingin mengajak pembaca mengedepankan perasaan untuk menghayati dan ikut prihatin, empati, memikirkan pemecahan masalah yang diketengahkan dalam karyanya. Pengarang menggunakan daya imajinya untuk

meyakinkan pembaca bahwa hal yang fiktif itu suatu kenyataan, sehingga pembaca dapat menangis, tertawa, terharu, dan sebagainya karena merasa menghadapi kenyataan.

Berdasarkan isi, cara, dan medium pengungkapannya di atas, maka dalam melakukan penghayatan terhadap isi karya sastra, pembaca sebagai penghayat harus mengedepankan faktor afektif, yaitu merupakan realitas rasa yang secara nyata ada pada diri pembaca. Diperlukan totalitas kekuatan emosional yang puncak pada diri pembaca ketika pengapresiasi sastra. Respon perasaan/ emosional siswa terhadap karya sastra terpengaruh dan selaras dengan pengalaman emosi yang telah terlabel dan tersimpan sebelumnya. Berkaitan dengan masalah kegiatan apresiasi sastra yang tidak dapat dilepaskan dari kekuatan emosional, maka tinggi-rendahnya kecerdasan emosional siswa sangat mempengaruhi keberhasilan siswa dalam apresiasi terhadap karya sastra (Suharto, 2011: 3-5)

Berdasarkan kajian teoretik dan kerangka berpikir, dapat dikemukakan hipotesis sebagai berikut: (1) ada perbedaan kemampuan menulis cerita pendek antara siswa yang diajar dengan model pembelajaran peta konsep dengan siswa yang diajar dengan model pengajaran Langsung; (2) ada perbedaan kemampuan menulis cerita pendek antara siswa yang kecerdasan emosionalnya tinggi dengan siswa yang kecerdasan emosionalnya rendah; (3) ada interaksi antara penggunaan model pembelajaran dan kecerdasan emosional dalam mempengaruhi kemampuan apresiasi prosa fiksi. 


\section{METODE PENELITIAN}

Penelitian ini dilaksanakan di SD se gugus Suryo Kecamatan Sine Kabupaten Ngawi. Penelitian ini dilaksanakan mulai bulan Juli 2021 sampai dengan bulan Desember 2021. Penelitian ini menggunakan rancangan desain faktorial $2 \times 2$, dan metode penelitian menggunakan quasi eksperiment atau eksperimen semu.

Variabel bebas pertama ialah penggunaan model pembelajaran yang terdiri dari level 1 model pembelajaran peta konsep dan level 2 model pengajaran langsung. Variabel bebas kedua ialah kecerdasan emosional (KE) yang terdiri dari level tinggi dan level rendah. Sedangkan Variabel terikat ialah kemampuan menulis cerita pendek.

Populasi berjumlah 150 siswa. Sampel penelitian terdiri dari empat SD. Dipilih 4 SD yang memiliki kualitas siswa yang seimbang. Teknik sampling yang digunakan ialah multyple stage purposive sampling. Sekolah eksperimen terdiri dari 2 SD diajar dengan model pembelajaran peta konsep, dan 2 SD yang lain diajar dengan model pembelajaran langsung. Instrumen penelitian ini menggunakan angket, tes, dan dokumen. Angket digunakan untuk memperoleh data kecerdasan emosional. Angket disusun menggunakan skala Liekert dengan 5 alternatif jawaban rating scalle. Tes digunakan untuk memperoleh data kemampuan menulis cerita pendek. Tes menulis cerita pendek dikembangkan dengan menggunakan bentuk tes penugasan menulis. Tes penugasan menulis cerita pendek berupa soal perintah mengarang cerita pendek dengan rambu-rambu petunjuk teknis mengarang.

Teknik analisis data dalam penelitian menggunakan teknik statistic Anava dua factor. Uji prasyarat analisis yang terdiri dari uji normalitas dan uji homogenitas. Selanjutnya analisis statistic menggunakan bantuan aplikasi SPSS.

\section{HASIL PENELITIAN}

Kemampuan menulis cerita pendek siswa dengan model pembelajaran peta konsep sebanyak 74 siswa, nilai minimal (min) sebesar 76; nilai maksimal (max) sebesar 97; rata-rata (Mn) sebesar 88,20; harga pertengahan (Me) sebesar 88; varian $\left(\mathrm{S}^{2}\right)$ sebesar 29,26; standar deviasi (S) sebesar 5,41. Kemampuan menulis cerita pendek siswa dengan model pembelajaran langsung sebanyak 52 siswa; nilai terendah sebesar 66; nilai tertinggi sebesar 95; Rata-rata sebesar 82,94; Median sebesar 83; Varians sebesar 47,15; Standar deviasi sebesar 6,87. Kemampuan menulis cerita pendek siswa dengan kecerdasan emosi tinggi sebanyak 65; nilai terendah sebesar 80; nilai tertinggi sebesar 97; Rata-rata sebesar 90,05; Median sebesar 90; Varians sebesar 17,39; Standar deviasi sebesar 4,17. Kemampuan menulis cerita pendek siswa dengan kecerdasan emosi rendah sebanyak 61 siswa; nilai terendah sebesar 66; nilai tertinggi sebesar 94; Rata-rata sebesar 81,75; Median sebesar 82; Varians sebesar 35,16; Standar deviasi sebesar 5,93 .

Perbandingan rata-rata siswa untuk masing-masing kelompok siswa berdasarkan model pembelajaran dan tingkat kecerdasan emosi dapat dilihat pada table sebagai berikut

Tabel 1. Nilai Rata-rata Kemampuan menulis cerita pendek siswa berdasarkan model pembelajaran dan kecerdasan emosi.

\begin{tabular}{lllll}
\hline Kelompok & Model PK- & Model PK- & Model Langsung & Model Langsung \\
& Kecerdasan & Kecerdasan & -Kecerdasan & -Kecerdasan \\
& Emosi Tinggi & Emosi Rendah & Emosi Tinggi & Emosi Rendah \\
\hline Nilai Rata-rata & 91,18 & 84,89 & 88,35 & 77,54 \\
\hline Standar Deviasi & 4,13 & 4,72 & 3,69 & 4,68 \\
\hline
\end{tabular}

Hasil uji prasyarat analisis, terdiri dari uji normalitas dan uji homogenitas, hasilnya dapat dilihat pada tabel-tabel di bawah ini. 
Tabel 2 : Hasil Uji Normalitas Hasil Belajar

\begin{tabular}{ccc}
\hline Sel & Kolmogorov-Smirnov Z & Asymp. Sig.(2 tiled) \\
\hline A1-B1 & 0,113 & 0,200 \\
\hline A1-B2 & 0,101 & 0,200 \\
\hline B2-B1 & 0,155 & 0,110 \\
\hline A2-B2 & 0,162 & 0,076 \\
\hline
\end{tabular}

Hasil uji normalitas data kemamuan menulis cerita pendek siswa yang diajar dengan model pembelajaran peta konsep dan kecerdasan emosi tinggi dan tingkat kecerdasan emosi dengan rumus Kolmogorov Smirnov diperoleh harga signifikansi > 0,05. Karena itu disimpulkan bahwa data masingmasing kelompok penelitian berdistribusi normal. Adapun hasil uji homogenitas, disajikan dalam table di bawah ini.

Tabel 3: Rangkuman Uji Homogenitas Levene,s

\begin{tabular}{cccc}
\hline $\mathrm{F}$ & df 1 & df 2 & signifikansi \\
\hline 1,004 & 3 & 122 & 0,394 \\
\hline
\end{tabular}

Dari tabel 3 di atas menunjukkan bahwa nilai signifikansi 0,394 lebih besar dari taraf signifikansi 0,05 $(0,394>0,05)$. Dengan demikian Ho tidak ditolak yang berarti semua kelompok data tersebut variannya homogen.

Dari hasil komputasi menggunakan aplikasi SPSS, pembuktian hipotesis disajikan dalam rangkuman di bawah ini/

Tabel 4: Rangkuman Hasil Pengujian Hipotesis

\begin{tabular}{|c|c|c|c|c|c|}
\hline Source & $\begin{array}{l}\text { Type III Sum of } \\
\text { Squares }\end{array}$ & df & Mean Square & $\mathrm{F}$ & Sig. \\
\hline Corrected Model & 3094,24 & 3 & 1031,41 & 54,91 & 0,00 \\
\hline Intercept & 891670,44 & 1 & 891670,44 & 47470,00 & 0,00 \\
\hline Model Pembelajaran & 790,36 & 1 & 790,36 & 42,08 & 0,00 \\
\hline Kecerdasan Emosi & 2230,21 & 1 & 2230,21 & 118,73 & 0,00 \\
\hline $\begin{array}{l}\text { Model Pembelajaran * } \\
\text { Kecerdasan Emosi }\end{array}$ & 155,38 & 1 & 155,38 & 8,27 & 0,00 \\
\hline Error & 2291,63 & 122 & 18,78 & & \\
\hline Total & 937970 & 126 & & & \\
\hline Corrected Total & 5385,873 & 125 & & & \\
\hline
\end{tabular}

Hasil analisis statistik Anava dua jalan dengan univariate analysis of variance, untuk variabel model pembelajaran didapatkan nilai $\mathrm{F}$ hitung sebesar 42,08 dan nilai signifikansi sebesar 0,000 . Setelah nilai signifikansi dikonsultasikan dengan taraf signifikansi 0,05 , ditemukan nilai signifikansi 0,000 lebih kecil dibanding 0,05 $(0,000<0,05)$. Dari hasil analisis tersebut, maka Ho yang menyatakan "tidak ada perbedaan Hasil Belajar Siswa yang diajar dengan model Pembelajaran Peta Konsep dan Siswa yang diajar dengan model pembelajaran Langsung" ditolak, dan $\mathrm{H}_{1}$ yang menyatakan "ada perbedaan Hasil Belajar Siswa yang diajar dengan model Pembelajaran Peta Konsep dan Siswa yang diajar dengan model pembelajaran Langsung", diterima. Hal ini berarti 
bahwa ada perbedaan Hasil Belajar Siswa yang diajar dengan model Pembelajaran Peta Konsep dan Siswa yang diajar dengan model pembelajaran Langsung".

Hasil analisis statistik Anava dua jalan dengan univariate analysis of variance untuk variabel kecerdasan emosi didapatkan nilai $\mathrm{F}$ hitung sebesar 118,73 dan nilai signifikansi sebesar 0,000 . Setelah nilai signifikansi dikonsultasikan dengan taraf signifikansi 0,05 , ditemukan nilai signifikansi 0,000 lebih kecil dibanding 0,05 $(0,000<0,05)$. Dari hasil analisis tersebut, maka Ho yang menyatakan "tidak ada perbedaan Hasil Belajar Siswa yang Kecerdasan Emosinya tinggi dengan Siswa yang Kecerdasan Emosinya rendah" ditolak, dan $\mathrm{H}_{1}$ yang menyatakan "ada perbedaan Hasil Belajar Siswa yang Kecerdasan Emosinya tinggi dengan Siswa yang Kecerdasan Emosinya rendah" diterima. Hal ini berarti bahwa ada perbedaan Hasil Belajar Siswa yang Kecerdasan Emosinya tinggi dengan Siswa yang Kecerdasan Emosinya rendah.

Hasil analisis statistik Anava dua jalan dengan univariate analysis of variance interaksi model pembelajaran dan kecerdasan emosi didapatkan nilai $\mathrm{F}$ hitung sebesar 8,27 dan nilai signifikansi sebesar 0,00. Setelah nilai signifikansi dikonsultasikan dengan taraf signifikansi 0,05, ditemukan nilai signifikansi 0,037 lebih kecil dibanding $0,05(0,000<0,05)$. Dari hasil analisis tersebut, maka Ho yang menyatakan "tidak ada interaksi antara penggunaan model pembelajaran dan kecerdasan emosi dalam mempengaruhi hasil belajar" ditolak, dan $\mathrm{H}_{1}$ yang menyatakan "ada interaksi antara penggunaan model pembelajaran dan Kecerdasan Emosi dalam mempengaruhi hasil belajar" diterima. Hal ini berarti bahwa ada interaksi antara penggunaan model pembelajaran dan kecerdasan emosi dalam mempengaruhi hasil belajar.

\section{PEMBAHASAN}

Peta konsep merupakan salah satu strategi yang dapat diterapkan dalam kegiatan pembelajaran. Pembelajaran yang menggunakan starategi peta konsep dilakukan dengan membuat konsep-konsep dari materi pembelajaran yang kemudian digambarkan dalam sebuah peta. Dalam peta tersebut terhadap garis hubungan antara konsep yang satu dengan konsep yang lainnya, sehingga dengan melihat peta konsep, maka akan mudah dipahami mana konsep yang awal mana konsep yang akhir, dan juga hubungan antara konsep-konsep tersebut menjadi lebih jelas. Pembelajaran dengan menggunakan peta konsep akan membentuk pola pikir pada siswa seperti dalam peta konsep. Dengan terbentuknya pola pikir tentang konsep-konsep materi pembelajaran diharapkan siswa mudah mengingat konsep apa saja dalam sebuah pembahasan dan bagaimana hubungan antar konsep tersebut. Dengan memiliki pola pikir konsep pembahasan materi pelajaran, maka siswa mudah mengingat materi-materi dalam pembelajaran.

Penelitian ini membandingkan pembelajaran dengan model pembelajaran peta konsep dan pembelajaran langsung pada pembelajaran menulis puisi. Dari hasil analisis diperoleh kesimpulan bahwa ada perbedaan yang signifikan pembelajaran dengan model konseptual dan pembelajaran langsung. kesimpulan ini menunjukkan bahwa model pembelajaran memberikan penagruh yang berbeda terhadap hasil belajar. Perbedaan hasil belajar kedua model pembelajaran dalam penelitian ini diketahui dari nilai rata-rata siswa dengan pembelajaran peta konsep sebesar 88,033 dan nilai rata-rata pada siswa dengan pembelajaran langsung sebesar 82,942. Dari kedua nilai rata-rata tersebut menunjukkan bahwa pembelajaran peta konsep memberikan pengaruh lebih besar terhadap hasil belajar siswa. Dengan nilai rata-rata tersebut maka hasil Uji beda rata-rata menunjukkan nilai yang signifikan, F hitung sebesar 42,077 dengan signifikansi sebesar 0,000. Jadi dalam penelitian ini membuktikan bahwa pembelajaran dengan peta konsep lebih baik dibandingkan dengan pembelajaran langsung.

Model pembelajaran peta konsep memang memiliki berbagai manfaat sebagaimana dikemukakan oleh DePorter (1994: 172) yang menyatakan empat manfaat yang diperoleh dari penggunaan Mind Mapping, yaitu: Keuntungan peta konsep (1) fleksible. Pembicara secara langsung mengingat untuk membuat point mengenai gagasan berikutnya, Anda dapat dengan mudah menambah ini pada tempat yang tepat pada Peta konsep Anda tanpa menyebabkan kebingungan. (2) Memfokuskan perhatian. Anda tidak peduli dengan menangkap setiap kata yang dikatakan. Bahkan, Anda dapat berkonsentrasi pada pemikiran. (3) Meningkatkan apresiasi. Ketika membaca suatu teks atau laporan teknis, Peta konsep meningkatkan apresiasi dan kemudian memberikan catatan review yang besar. (4) Menyenangkan. Imajinasi dan kreativitas Anda adalah 
tak terbatas, dan itu membuat mengambil dan meninjau catatan lebih menarik. Peta konsep (Mind Mapping) memungkinkan otak menggunakan semua gambar dan asosiasinya dalam pola radial dan jaringan sebagaimana otak dirancang seperti yang secara internal selalu digunakan otak, dan anda perlu membiasakan diri kembali. Peta konsep (Mind Mapping) merupakan cara termudah untuk menempatkan informasi ke dalam otak dan mengambil informasi ke luar dari otak. Peta konsep (Mind Mapping) adalah cara mencatat yang kreatif, efektif, dan secara harfiah akan "memetakan" pikiran-pikiran kita (Buzan, 2007: 4).

Hasil penelitian menunjukkan bahwa ada perbedaan yang signifikan kecerdasan emosi tinggi dengan kecerdasan emosi rendah. Hal ini ditunjukkan dngan hasil uji $F$ sebesar 118,73 dengan signifikansi $0,000<0,05$. Dengan adanya perbedaan yang signifikan tersebut maka dapat disimpulkan bahwa kecerdasan emosi dapat mempengaruhi hasil belajar siswa.

Sebagaimana dinyatakan di atas bahwa setiap siswa memiliki kecerdasan yang berbeda-beda. Kemampuan masing-masing siswa yang berbeda karena pada dasarnya tiap individu mempunyai karakteristik (bakat, kecerdasan, emosi, dan lain-lain) yang berbeda. Perbedaan kemampuan masing-masing siswa ini mempengaruhi proses belajar. Emosi dimiliki oleh setiap individu siswa. Emosi dapat berbentuk negatif atau positif. Emosi positif dapat memotivasi secara internal yang pada gilirannya dapat membangun diri, misalnya menjadi menyukai belajar, mau bergaul, bila mendapat kegagalan cepat bangkit untuk berusaha mencapai keberhasilan. Sedangkan emosi negatif bersifat destruktif atau merusak, misalnya murung, putus asa, menarik diri, takut, malu, dan sebagainya. Keadaan ini pun sangat mempengaruhi belajarnya. Siswa akan mengalami learning disability (ketidak-mampuan belajar) atau difficult learning (kesulitan belajar) missconcepsi (kesalahan konsep), attention deficit (kurang perhatian) dalam proses belajarnya. Goleman (2001: 22) menjelaskan bahwa ketika otak menerima tekanan atau ancaman, maka kapasitas saraf untuk berpikir rasional mengecil. Otak dibajak secara emosional (Suharto, 2011: 3-5)

Berkaitan dengan masalah kegiatan apresiasi sastra yang tidak dapat dilepaskan dari kekuatan emosional, banyak penelitian menguatkan adanya hubungan antara keterlibatan emosi, memori jangka panjang, dan belajar/ apresiasi sastra (Goleman, 2005: 14; DePorter, 2000: 22). Ikatan emosional akan memperkuat memori dan ingatan siswa terhadap bahan-bahan yang dipelajari yang selanjutnya menuntun kegiatan belajarnya. Hal ini dikarenakan emosi menentukan kepekaan subjektif yang mendorong dan mengontrol gagasan dan kecenderungan bertindak dalam berbagai aktivitas manusia. Sistem limbiklah yang mengatur rangsangan bagian otak dan menerima perintah dari semua sistem sensasi (Kassim, 2000: 16). Stimulus (input) yang merangsang seseorang akan merangsang organ visera dalam badan dan kemudian mengakibatkan terkumpulnya emosi atau pengalaman emosi dan perubahan pada perasaan. Terkumpulnya pengalaman emosi ini selaras dengan teori emosi kognitif (Kassim, 2000: 17-19) yang menyatakan bahwa respon perasaan/ emosi akan terjadi/ terpengaruh selaras dengan pengalaman emosi yang telah terlabel dan tersimpan sebelumnya.

\section{DAFTAR PUSTAKA}

Abdul Azis Wahab. 2008. Metode dan Model-Model Mengajar. Bandung: Alfabeta

Abdul Majid. 2008. Perencanaan Pembelajaran: Mengembangkan Standar Kompetensi Guru. Bandung: Rosda

Ahmad Sudrajad. 2008. Komparasi Pembelajaran Konstruktivistik dengan Behavioristik. (dalam http://www.akhmadsudrajat.wordpress.com. Diunduh tanggal 14 April 2009)

Ajib Rosidi. 1973. Pembinaan Minat Baca, Apresiasi dan Penelitian Sastra. Jakarta: Gunung Agung

Akkuyunlu, Buket dan Soylu, Meryem Yilmaz. 2008. "Study of Student's Perceptions in a

Blended Learning Environment Based on Different Learning Styles". Journal of

Educational Technology \& Society. Vol. 11. No. 1. (Pp. 183-193)

Aminudin. 1984. Pengantar Memahami Unsur-unsur dalam Karya Sastra. Malang: IKIP Malang.

Aminudin. 1995. Pengantar Apresiasi Karya Sastra. Bandung: Sinar Baru, Algensindo. 
Anderson, Lorin W. \& Krathowohl, David R. 2001: A Taxonomy for Learning, Teaching and Assessing: A Revision of Bloom's Taxonomy of Educational Objectives. New York: Longman

Suharto, V Teguh. 2011. Perbrdaan Keefektifan Model PEmbelajaran Experiental Learning dan Model PEmbelajaran Langsung dalam Pembelajaran APresiasi Prosa Fiksi Ditinjau dari Kecerdasan Emosional Siswa. Jurnal Pendidikan Vol 17 nomor 2. (Diakses 24 Desember 2021) 